Int.J. Hum. Soc. Dev. Res.

ISSN(P):2521-1439; ISSN(E):2523-4331

Volume 2, Number 1, 2018. 81-93

DOI:10.30546/2523-4331.2018.2.1.81

\title{
A STUDY ON THE LIFE AND LEISURE SATISFACTION LEVELS OF OFFENDERS PARTICIPATING IN THERAPEUTIC RECREATIONAL ACTIVITIES
}

\section{Hüseyin ÖZTÜRK}

Gaziantep University, Turkey

\section{(C) The Author(s) 2018}

\begin{abstract}
This study was conducted to deter the effect that recreational activities has on the life satisfaction levels and leisure time of offenders under the jurisdiction of Gaziantep Probation Office. The study sample consisted of 206 offenders under the jurisdiction of Gaziantep Probation Office. These offenders participated in recreational activities, namely basketball, volleyball and educational games, for 24 weeks.

The study data consists of the participants' answers to questions that specify demographic information, and to questions regarding leisure time and life satisfaction. As a result of the study, it was found that there is a significant difference in Life Satisfaction Scale depending on educational background and length of time offenders serve. In addition to this, it is clear that there is a significant difference and connection between Leisure Satisfaction and Life Satisfaction Scales.

\section{C2018.All rights reserved}

\section{ARTICLE HISTORY}

Received: 29/12/2017

Accepted: 28/03/2018

Published online: 01/04/2018

\section{KEYWORDS}

Therapeutic Recreation, Offender, Leisure Time Activity, Life

Satisfaction 


\section{Introduction}

The number of crimes being perpetrated in Turkey and all over the world is increasing rapidly. Therefore there is a need for preventive efforts to reduce increasing crime levels. Therapeutic recreation can be practiced as a significant factor to prevent and lower crime rates.

Therapeutic recreation can be practiced as an educational method to lower crime rates, prevent depression, and decrease levels of stress and anxiety, and offer alternatives to prevent nervous breakdowns among offenders, while it also helps them to take a positive approach to their judiciary process.

The basic goal of this study is to clarify the connection between leisure time activities - life satisfaction and therapeutic activities. Therapeutic recreation is a functional service which turns leisure time activities into a habit and positively affects life satisfaction (Rothwell and Piaat, 2006,243). Therapeutic recreation is a medically approved treatment method practiced on people who have physical, mental or emotional problems in the presence of professional experts (Dustin, 2000,79). Therapeutic recreation contributes to the social, mental or spiritual recovery of individuals and helps them change their behaviors (Bunte et al., 2008, 83).

Therapeutic recreation allows an individual to gain new skills and social functions (Whoqol, 1998,551; Dustin, 2000, 82). It is a complementary activity which decreases or prevents health problems. At the same time, it is a personal development supporter to protecting our health (Auatin and Crawford, 2001,9).

Leisure time activities have a number of positive effects on anxiety (Kelly et al., 1987,189; Mannel, 1980,62; Tinsley and Tinsley,1986,2). People who have healthy lifestyles use an approach of avoiding negative emotions, thoughts and bad habits (Stumbo and Peterson, 2010,3). 
Therapeutic recreation not only supports the benefit of participating in leisure time activities, but also helps avoid the disadvantages arising during the leisure time of individuals (Caldweel, 2005, 9). It is a service which uses leisure time activities to protect life values and provide individuals with a variety of positive experiences and which has an active role in recovery (Carruthers and Hood, 2007,281).

Therapeutic recreation pays particular regard to the uniqueness of individuals and focuses on the differences and the results of their improvements. It helps individuals to make advances, recover their physical and mental health, increase their functional capacity, exhibit a positive change in their behaviors, and equips them with values such as finding purpose and meaning in life (Ross and Ashton-Shaeffer, 2001,52; Shank and Coyle, 2002,25; Daly, Kunstler, 2010,8).

Leisure time is a chance for individuals to act freely and has positive reflections on the individuals themselves and their relationships with other people. This aspect of the leisure experience is also applied in the field of therapeutic recreation, as well as in various fields of leisure time (Dattilo and Kleiber, 1993,58). Therapeutic recreation has the advantage of providing this feature to individuals under different conditions (Rothwell and Piaat, 2006, 243). It reduces inappropriate behavior by increasing interaction between people, encouraging them to work together and socialize(Daly et al.,2006,18).

As a result, it is concluded that leisure time activities have positive effects on the quality of life of offenders who participate in them. Providing opportunities in which offenders can make efficient use of their free time contributes to both the offenders themselves and society.

\section{Material And Methods:}

In this section, the design and the index of research, data collection and statistical methods used to obtain data will be discussed. 


\section{Study Method}

This study is based on the relational screening method (Karasar, 2002, Şenduran and Donuk, 2009; Güzel et al., 2009). This research method focuses on finding connections between the circumstances and characteristics of cases, rather than the reasons behindthem (Creswell, 2005; Kaptan, 1995; Arslan et al., 2011). Using this method allowed the study to providean inside perspective on the effects that leisure time activities had on the life satisfaction of offenders who participated in therapeutic recreation activities.

\section{Target Population and Sample}

The target population of the study was offenders under the jurisdiction of Gaziantep Probation Office. The mass sampling method, which is not a stochastic method,was followed up when specifying the method of the survey. The personal information of the target population is shown in Table 1.

Table 1: Personal informationof target population

\begin{tabular}{llll}
\hline Population & $\mathbf{N}$ & $\mathbf{F}$ & $\mathbf{\%}$ \\
\hline \multirow{3}{*}{ Age } & $18-24$ & 35 & 17 \\
\cline { 2 - 4 } & $25-31$ & 69 & 33.5 \\
\cline { 2 - 4 } & 32 and Over & 102 & 49.5 \\
\hline \multirow{3}{*}{ Marital Staus } & Married & 120 & 58.3 \\
\hline \multirow{3}{*}{ Education } & Single & 86 & 41.7 \\
\hline \multirow{2}{*}{ Primary and } & Secondary & 169 & 82 \\
& School & & \\
\cline { 2 - 5 } & HighSchool & 37 & 18 \\
\hline & Employed & 96 & 46.6 \\
\cline { 2 - 4 }
\end{tabular}




\begin{tabular}{llll}
\cline { 2 - 4 } Occupation & Retired & 25 & 12.1 \\
\cline { 2 - 4 } & Unemployed & 85 & 41.3 \\
\hline \multirow{3}{*}{ Length of Sentence } & 1-3 Years & 110 & 53.4 \\
\cline { 2 - 4 } & 4-6 Years & 49 & 28.8 \\
\cline { 2 - 4 } & 7 Years and Over & 47 & 22.8 \\
\hline
\end{tabular}

Table 1 details the personal information of the target population and their answers to the related questions. According to this, it shows that individuals who participated in the study were mostly (49.5\% -102 people) at the age of 32 and over, were mostly (58.3\% - 120 people) married, were mostly ( $82 \%$ 169 people) educated toprimary and secondary school level, were mostly (\% 46.6-96 people) laborers and were mostly (53.4\% -110 people) serving sentences between $1-3$ years.

\section{Data Collection Tool}

In this study Beard and Raghep's (1980) study on the Leisure Satisfaction Scale and Diener et al.'s study on the Life Satisfaction Scale (1985) were used to evaluate the effects of leisure time activities on the life satisfaction of offenders who participated in therapeutic activities. The Turkish version of the scale benefits from Sevil's validity and authenticity study (2005). The Quinary Likert Scale was used in each of the studys cales.

The Leisure Satisfaction Scale is formed of the Psychological Scale (4 articles), Educational Satisfaction (4 articles), Social Satisfaction (4 articles), Recovery Satisfaction (4 articles), Physiological Satisfaction (4 articles), and Aesthetic Satisfaction (4 articles) and the Life Satisfaction Scale is formed of one dimension (5 articles). 


\section{Analysis of Data}

KMO analysis was used to test the size of the sample. The result of the KMO (Kaiser-Meyer-Olkin) test was clearly larger than 0.60 and thus Bartlett is $(p<0.001)$ purposeful. Hence, it indicates that the study has enough samples and a structure that is determinable. According to this, the reliability coefficient of the Leisure Satisfaction Scale was examined and it was found that the Cronbach alpha is 0.75 and the Life Satisfaction Scale's reliability coefficient alpha is 0.82 .

The Kolmogorov Smirnov test was used to test the suitability of the normal distribution of continuous variables. The T-Test was used for comparison of two independent target populations, ANOVA and LSD multiple comparison tests for more than two different target populations, and the frequency and percentage of statistics are scaled in this study. $\mathrm{p}<0.05$ is considered significant in the statistical analysis.

\section{Results:}

This section consists of the study's indications.

Table 2: Differentiation of Sub-dimensions of Leisure Satisfaction Scale and Life Quality Scale Depending on Educational Background

\begin{tabular}{cllllll}
\hline \multicolumn{1}{c}{ Factors } & Educational Background & $\mathbf{N}$ & Ort & Ss & $\mathbf{t}$ & P \\
& & \multicolumn{2}{c}{$\cdot$} & & & \\
\hline $\begin{array}{c}\text { 1.Pyschological } \\
\text { Satisfaction }\end{array}$ & $\begin{array}{l}\text { Primary and Secondary } \\
\text { School }\end{array}$ & 169 & 2.26 & 0.85 & 0.67 & 0.40 \\
& High School & 37 & 2.36 & 0.62 & & \\
\hline 2.Social & Primary and Secondary & 169 & 1.93 & 1.15 & 1.67 & 0.09 \\
Satisfaction & School & & & & & \\
& High School & 37 & 1.60 & 0.63 & & \\
\hline 3.Aesthetic & Primary and Secondary & 169 & 1.98 & 0.92 & 1.00 & 0.31 \\
Satisfaction & School & & & & &
\end{tabular}




\begin{tabular}{cllllll} 
& High School & 37 & 1.80 & 1.14 & & \\
\hline 1.Life & Primary and Secondary & 169 & 2.60 & 0.92 & 3.46 & $\mathbf{0 . 0 1}$ \\
Satisfaction & School & & & & & $*$ \\
& High school & 37 & 2.03 & 0.79 & & \\
& & & & & & \\
\hline
\end{tabular}

$\mathrm{p}<0.05$

Table 2 indicates that there is no significant difference between the subdimension points of the Leisure Satisfaction Scale depending on the educational background of participants [Psychological Satisfaction $(\mathrm{t}=0.67$, $p>0.05)$, Social Satisfaction ( $t=1.67, p>0.05)$, Aesthetic Satisfaction ( $t=1.00$, $\mathrm{p}>0.05)$ ] and that there is a significant statistical difference in total points of Life Satisfaction ( $\mathrm{t}=3.46, \mathrm{p}<0.05)$. According to this result, participants who were educated to primary and secondary school level achieved higher points in Life Satisfaction than participants who graduated from high school.

\section{Table 3: Differentiation of Sub-dimensions of Leisure Satisfaction Scale and Life Quality Scale Depending on Length of Sentence}

\begin{tabular}{|c|c|c|c|c|c|c|c|}
\hline & Status & $\mathbf{n}$ & Mean & S.s. & f & $\mathbf{p}$ & $\begin{array}{l}\text { Significant } \\
\text { Difference }\end{array}$ \\
\hline 1.Pyschological & $1-3$ Years & 110 & 2.36 & 0.87 & & & \\
\hline Satisfaction & 4-6 Years & 49 & 2.13 & 0.75 & 1.46 & $\begin{array}{ll} & 0.2 \\
3 & \end{array}$ & \\
\hline & 7 Years and Over & 47 & 2.23 & 0.69 & & & \\
\hline 2.Social & 1-3 Years & 110 & 1.93 & 1.14 & & & \\
\hline Satisfaction & 4-6 Years & 49 & 1.79 & 0.98 & 0.32 & $\begin{array}{ll} & 0.7 \\
2 & \end{array}$ & \\
\hline & 7 Years and Over & 47 & 1.83 & 1.02 & & & \\
\hline 3.Aesthetic & 1-3 Years & 110 & 2.09 & 1.00 & & & \\
\hline
\end{tabular}


Hüseyin ÖZTÜRK

\begin{tabular}{|c|c|c|c|c|c|c|c|}
\hline Satisfaction & 4-6 Years & 49 & 1.73 & 0.85 & 2.88 & 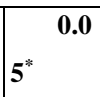 & $\mathbf{a}>\mathbf{b}$ \\
\hline & 7 Years and Over & 47 & 1.82 & 0.91 & & & \\
\hline & 1-3 Years & 110 & 2.50 & 0.90 & & & \\
\hline 4. Life Satisfaction & 4-6 Years & 49 & 2.73 & 0.83 & 3.32 & $3^{*}$ & b>c \\
\hline & 7 Years and Over & 47 & 2.25 & 1.00 & & & \\
\hline
\end{tabular}

$\mathrm{p}<0.05$

Table 3 indicates that there is no significant difference statistically between Aesthetic Satisfaction, which is a sub-dimension of the Leisure Satisfaction Scale depending on the sentence lengths of the participants $(\mathrm{f}=2.88, \mathrm{p}<0.05)$. Other sub-dimensions do not have a significant difference [Psychological Satisfaction $(\mathrm{f}=1.46, \mathrm{p}>0.05)$, Social Satisfaction $(\mathrm{f}=0.32$, $\mathrm{p}>0.05)]$. According to the result, participants who are sentenced to 1-3 years get more points from Aesthetic Satisfaction than participants who are sentenced 4-6 years.

There is no significant difference considering the Life Satisfaction Scale points depending on sentence length factor $(\mathrm{f}=3.32, \mathrm{p}<0.05)$. According to this result, participants who are sentenced to 4-6 years get more points than the participants who are sentenced to7 or more years.

Table: 4 Correlation Table on Life Satisfaction Scale and Leisure Satisfaction Scale Sub-Dimension Points

\begin{tabular}{llll}
\hline & $\mathrm{n}$ & $\mathrm{r}$ & $\mathrm{p}$ \\
\hline Psychological Satisfaction & 206 & 0.232 & $\mathbf{0 . 0 0 1}^{* *}$ \\
Social Satisfaction & 206 & 0.258 & $\mathbf{0 . 0 0 0}^{* *}$ \\
AestheticSatisfaction & 206 & 0.233 & $\mathbf{0 . 0 0 1}^{* *}$ \\
\hline $\mathrm{p}<0.05$ & & &
\end{tabular}


Table 4 indicates that Psychological Satisfaction( $\mathrm{r}=0.232, \mathrm{p}=0.001)$, Social Satisfaction $(\mathrm{r}=0.258, \mathrm{p}=0.000)$ and Aesthetic Satisfaction( $\mathrm{r}=0.233$, $\mathrm{p}=0.001$ ), which are sub-dimensions of the Life Satisfaction Scale points, and Leisure Satisfaction Scale points have a low correlation in a positive way. According to this result, the life satisfaction of the participants will increase positively.

\section{Discussion}

It is seen that there is no significant difference in the Leisure Satisfaction Scale in relation to the education status of the offenders who participated in the study.

Studies which indicate similarities and differences between the results and the Leisure Satisfaction Scale and Life Satisfaction Scale include; Van der Meer(2008), who observed people with disabilities who participated in recreational activities in relation to their education status, and whose results show that the more educated they are the more they participate, Lu and Kao(2009), who found that elderly people who participated in recreational activities and have educational degrees also have a higher Psychological Satisfaction Scale, Nimrod (2007) and Quelette (1995), who found that elderly people who participated in recreational activities and have educational degrees also have a higher Life Satisfaction Scale, Bechetti et al.(2010), who found that elderly people's educational level affects their perception of life satisfaction, and Fonseca et al., who found that recreational activities are effective factors in the high education level of elderly people(2008). 
According to the study, there is a significant statistical difference between the Leisure Satisfaction Scale and Aesthetic Satisfaction related to the sentence length of the offenders who participated in recreational activities. Offenders who are sentenced to1-3 years get higher points in the Aesthetic Satisfaction Scale compared to offenders who are sentenced to 4-6 years. There is also a significant difference in the Life Satisfaction Scale and it shows that offenders who are sentenced for 4-6years get higher points compared to the offenders who are sentenced for 7 years and more.

Offenders whose sentence lengths are lower get higher points in the Leisure Satisfaction Scale, Aesthetic Satisfaction Scale and Life Satisfaction Scale. According to this, participating in recreational activities contributes to the offenders positively. There are some studies supporting this result.

Brajsa-Zganec et al. found that participating in recreational activities improves social relations and positive feelings (2011). Dülger also found that recreational activities help people to get rid of negative thoughts, to find a place in society, to realize their potential, to stay healthy and to be successful $(2012,31)$.

The results show that there is a positive significant connection between the points of the Life Satisfaction Scale and psychological, social, aesthetic satisfaction, which are the sub-dimensions of the Leisure Satisfaction Scale. According to this, the life satisfaction of the offenders who participate in therapeutic recreational activities increases. There are studies which support these results.Jim and Chen found that leisure satisfaction consists of passive, comforting and individualistic activities during the aging process (2009). Siegenthaler and Vaughan found that leisure time activities help the elderly to feel better in socially and psychologically and to gain a joy for living 
(1998). Kaostates that there is a connection between participating in leisure time activities and leisure satisfaction (1992).As a result of participation in recreational activities, due to the positive effect on the perception of participants, leisure satisfaction should increase (Huang and Carleton, 2003). It is concluded that the leisure satisfaction degree of participants affects their quality of life in a positive way and that leisure satisfaction, aesthetic and psychological satisfaction factors influence the life satisfaction scale (Lloyd and Auld, 2002). This study shows that there is a connection between leisure satisfaction and life satisfaction and that social, aesthetical and psychological satisfaction scales are effective (Procidano et al., 2004).

It is concluded that providing leisure satisfaction has an effect on life satisfaction (Procidano et al., 2004). Leisure satisfaction which comes from participation in leisure time activities is a significant factor in terms of life satisfaction (Huang, 2003). Participation in leisure time activities is one of the most important and distinctive features of life satisfaction (Spiers and Walker, 2008; Iwasaki, 2007). Therapeutic recreational activities that provide social quality of life have positive effects on life satisfaction (Zabriskie et al. 2005). Studies indicate that there is a positive connection between leisure satisfaction, life satisfaction and quality of life. Life satisfaction plays a significant role in increasing life quality (Mannel, 2007).

\section{Conclusion and Suggestions}

According to the study, participating offenders with a higher level of education have a higher level of psychological satisfaction and participants who have a lower level of education have a high level of life satisfaction compared to those with a high level of education. It is concluded that participating offenders who have shorter sentences have a higher level of aesthetic and life satisfaction. Offenders who participated in recreational activities indicate that they are satisfied with leisure time activities and that it contributes to their lives in a positive way. The number of crimes perpetrated in Turkey and across the world is increasing rapidly and there must be an environment in which people can live liberally and establish 
social relations to discharge emotions in order to prevent them from committing crime. It is suggested that offenders are provided with the opportunity to participate in recreational activities. In conclusion, governors should work with recreational education experts in a process of improving and practicing therapeutic projects to increase the social adjustment of offenders and decrease the potential of reoffending in order to create a healthy society.

It is suggested to follow and develop the policy of employing recreational education experts in institutions where people may be obliged to spend long periods of time, such as educational institutions, prisons, hospitals and nursing homes.

\section{Disclosure statement}

No potential conflict of interest was reported by the author.

\section{Contact Information}

E-mail: ozturk@gmail.com 


\section{References and notes:}

AMABILE, T. M (1996). Creativity and innovation in organizations (Vol. 5). Boston, Harvard Business School.

BECHERER, R. C, MENDENHALL, M. E and EICKHOFF, K. F (2008). Separated at birth: An inquiry on the conceptual independence of the entrepreneurship and the leadership constructs. New England Journal of Entrepreneurship, 11 (2),pp. 13-27.

Bandura, A. (1986). Social foundations of thought and action. Englewood Cliffs, NJ: Prentice Hall.

Bandura, A. (2000). Cultivate self-efficacy for personal and organizational effectiveness. Handbook of principles of organizational behavior, pp.120-136.

Bandura, A. (2006). Guide for constructing self-efficacy scales. Self-efficacy beliefs of adolescents, 5, pp.307337.

Barbosa, S. D., Kickul, J., Gundry, L. K., \& Whitcanack, L. (2009). Intuition Versus Analysis? Testing Differential Models of Cognitive Style on Entrepreneurial Self-Efficacy and the New Venture Creation Process. Entrepreneurship Theory and Practice, 33(2), pp.439-453.

BarNir, A., Watson, W. E., \& Hutchins, H. M. (2011). Mediation and Moderated Mediation in the Relationship among Role Models, Self-Efficacy, Entrepreneurial Career Intention, and Gender. Journal of Applied Social Psychology, 41(2),pp. 270-297.

Baum, J. R., \& Locke, E. A. (2004). The relationship of entrepreneurial traits, skill, and motivation to subsequent venture growth. Journal of applied psychology, 89(4), p.587.

Chen, C. C., Greene, P. G., \& Crick, A. (1998). Does entrepreneurial self-efficacy distinguish entrepreneurs from managers? Journal of business venturing, 13(4),pp. 295-316.

Chen, G., Gully, S. M., \& Eden, D. (2001). Validation of a new general self-efficacy scale. Organizational research methods, 4(1), pp.62-83.

Coakes, S. J., \& Steed, L. (2009). Analysis without anguish using SPSS version 14.0 for Windows. (14.0 ed.). John Wiley \& Sons, Inc.

Cohen, L., Manion, L., \& Morrison, K. (2013). Research methods in education. Routledge.

Creswell, J. W. (2008). Research Design: Qualitative, Quantitative, and Mixed Methods Approaches (3rd Edition ed.). Sage Publisher.

Ford, D. Y, and Harris, J (1992). The elusive definition of creativity. The Journal of Creative Behavior, 26 (3), pp.186-198.

Hamidi, D. Y, Wennberg, K and Berglund, H (2008). Creativity in entrepreneurship education. Journal of Small Business and Enterprise Development, 15 (2), pp.304-320.

Hunter, S. T, Bedell, K. E and Mumford, M. D (2007). Climate for creativity: A quantitative review. Creativity research journal, 19 (1), pp.69-90.

Mcgee, J. E, et al. (2009). Entrepreneurial Self-Efficacy: Refining the Measure. Entrepreneurship Theory and Practice, 33 (4), pp.965-988.

Mcmullen, J. S, and Shepherd, D. A (2006). Entrepreneurial action and the role of uncertainty in the theory of the entrepreneur. Academy of Management Review, 31 (1),pp. 132-152.

Oke, A, Munshi, N and Walumbwa, F. O (2009). The influence of leadership on innovation processes and activities. Organizational Dynamics, 38 (1),pp. 64-72.

Petrowski, M. J (2000). Creativity research: implications for teaching, learning, and thinking. Reference Services Review, 28 (4), pp.304-312.

Pihie, Z. A. L, and Bagheri, A (2013). Self-Efficacy and Entrepreneurial Intention: The Mediation Effect of SelfRegulation. Vocations and Learning, 6 (3), pp.385-401.

Segal, G, Borgia, D and Schoenfeld, J (2005). The motivation to become an entrepreneur. International Journal of Entrepreneurial Behavior \& Research, 11 (1), pp.42-57

Ward, T. B. (2004). Cognition, creativity, and entrepreneurship. Journal of business venturing, 19(2),pp. 173188.

West, M. A., \& Altink, W. M. (1996). Innovation at work: Individual, group, organizational, and socio-historical perspectives. European Journal of Work and Organizational Psychology, 5(1), pp.3-11.

Whiting, B. G. (1988). Creativity and entrepreneurship: how do they relate? The Journal of Creative Behavior, 22(3), pp.178-183.

Young, J. (1985). What is creativity? Journal of Creative Behavior, 19(2),pp. 77-87.

Zhao, H, Seibert, S. E and Hills, G. E (2005). The mediating role of self-efficacy in the development of entrepreneurial intentions. Journal of applied psychology, 90 (6), p.1265. 